\title{
Pediatric Cyanide Poisoning After Ingestion of Apricot Seeds
}

\author{
Çocuklarda Kayısı Çekirdeği Yenmesi Sonrası Siyanür Zehirlenmesi
}

\author{
(1) Yüksel Bıcılıoğlu1 , (1) íhsan Yıldırım¹, (1) Pınar Yazıcı Özkaya2, (1) Alkan Bal3 \\ ${ }_{1}^{1}$ Şanlıurfa Training and Research Hospital, Clinic of Pediatric Emergency, Şanlıurfa, Türkiye \\ 2Ege University Faculty of Medicine, Department of Pediatric Intensive Care, Izmir, Turkey \\ 3 Manisa Celal Bayar University Faculty of Medicine, Department of Pediatric Emergency, Manisa, Turkey
}

\section{Abstract}

Cyanide is one of the strongest and lethal poisons. Cyanide leads to tissue hypoxia and lactic acid accumulation. Hydroxocobalamin is a safe, fast and effective antidote that could be used, especially in children. In this paper, we presented four cases of cyanide poisoning caused by apricot seed ingestion. Three of the patients were transferred to the paediatric intensive care unit, and hydroxocobalamin was given, and their conditions improved rapidly. This study aimed to draw attention to cyanide poisoning caused by apricot seed ingestion and to hydroxocobalamin use as an antidote.

Keywords: Childhood, cyanide, hydroxocobalamine, poisonning

\section{Öz}

Siyanür en güçlü ve en ölümcül zehirlerden biridir. Siyanür doku hipoksisine ve laktik asid oluşumuna neden olur. Hidroksikobalamin, özellikle çocuklarda kullanılabilecek güvenli, hızı ve etkin bir antidottur. Biz bu yazıda kayısı çekirdeği alımına bağlı siyanür zehirlenmesi olan dört olgu sunduk. Üç hastamızda ciddi zehirlenme bulguları ile çocuk yoğun bakım ünitesine alındı ve andidot olarak hidroksikobalamin verilerek, hızlı düzelme sağlandı. Amacımız; kayısı çekirdeği yenmesine bağlı siyanür zehirlenmesine ve antidot olarak hidroksikobalamin kullanımına dikkat çekmektir.

Anahtar Kelimeler: Çocukluk çağı, siyanür, hihroksikobolamin, zehirlenme

\section{Introduction}

Cyanide is one of the most potent and lethal poisons. Smoke inhalation, industrial accidents, toxic substance intake with domestic and workplace incidents, suicide attempts, terrorist attacks and cyanogenic food intake producing cyanide can result in cyanide poisoning. ${ }^{1,2}$ Oral cyanide intoxication results from oral ingestion of several foods containing cyanogenic glycosides. ${ }^{3}$ Apricot seeds are more toxic than others because of their high cyanogen concentration and their ability to easily release hydrogen cyanide contents. Apricot seeds do not release cyanide in large amounts; however, their toxicity increases when chewed. It is known that the cyanide content of apricot ranges between 0.089 and $2.17 \mathrm{mg} / \mathrm{g}$ and that previous studies found a fatal dose of between 0.56 and $1.52 \mathrm{mg} / \mathrm{kg}^{4}{ }^{4}$ Cyanide causes tissue hypoxia by inhibiting cytochrome oxidase. As a result of anaerobic metabolism, lactic acidosis with high anion-gap develops. ${ }^{5,6}$ Mortality rate is higher in patients who are not diagnosed and treated immediately. ${ }^{7,8}$ The absence of underlying chronic disease, sudden onset of clinical findings, a history of food intake containing cyanogenic glycosides and a bitter almond smell in the breath suggest the diagnosis of cyanide intoxication. ${ }^{9-11}$ Serum cyanide level should be measured in cases with a suspicion of cyanide intoxication. ${ }^{12}$ In serious cases (mental changes, severe metabolic acidosis, convulsion and resistant hypotension), accurate and rapid antidote treatments are life saving. Drugs including sodium thiosulfate, sodium nitrite, amyl nitrite and hydroxocobalamin can be used as antidotes. Hydoxycobalamin has become an ideal antidote especially in children because of the potential side effects of nitrites. .3,14 $^{13}$

In the literature, there are a few studies evaluating cyanide poisoning in children due to apricot seed ingestion. Therefore, we aimed to evaluate cyanide poisoning due to apricot seed ingestion consumption and hydroxocobolamine use in cyanide poisoning.

Yazışma Adresi/Address for Correspondence: Alkan Bal, Manisa Celal Bayar University Faculty of Medicine, Department of Pediatric Emergency, Manisa, Turkey E-posta: balalkan@hotmail.com ORCID ID: orcid.org/0000-0002-7884-1251 Geliş Tarihi/Received: 01.10.2018 Kabul Tarihi/Accepted: 17.03.2019

-Telif Hakkı 2020 çocuk Acil Tıp ve Yoğun Bakım Derneği

Çocuk Acil ve Yoğun Bakım Dergisi, Galenos Yayınevi tarafından yayınlanmıştır 


\section{Case Reports}

\section{Case 1}

A 2-year-old girl was transferred by the emergency medical services (EMS) to the pediatric emergency department (PED) with complaints of vomiting, respiratory distress, cyanosis and loss of consciousness (LOC) that developed 30 min after eating a handful of fresh apricot seeds. Initial evaluation of the patient revealed tachycardia (150 beats/min), prolonged capillary refill time (5-6 s), hypotension $(60 / 25 \mathrm{mmHg})$, low Glasgow Coma scale [(GCS) 5/15], mydriatic pupils, poor light reflex and hypopnea. The patient was intubated, and intravenous fluid treatment and dopamine infusion $(5 \mathrm{mcg} /$ $\mathrm{kg} / \mathrm{min}$ ) were administered. Blood gas analysis showed high anion-gap metabolic acidosis and high lactate level (Table 1). Her complete blood count (CBC), biochemical values and coagulation parameters were within normal limits. Based on physical, clinical and laboratory findings and apricot seed ingestion history, acute cyanide poisoning was considered, and the patient was transferred to the pediatric intensive care unit (PICU). As early as $8 \mathrm{~h}$ after admission, hydroxocobalamin $(70 \mathrm{mg} / \mathrm{kg}$ ) infusion was administered. After $12 \mathrm{~h}$ of the hospitalisation, dopamine treatment was stopped, and the patient was extubated. On the second day, the patient was discharged from the PICU.

\section{Case 2}

A 3-year-old boy was admitted by EMS to the PED with respiratory distress and LOC. He complained of abdominal pain, nausea and vomiting after eating six to seven apricot seeds. The initial evaluation of the patient revealed tachycardia (150 beats $/ \mathrm{min})$, prolonged capillary refill time (4-5 s), hypotension $(60 / 40 \mathrm{mmHg})$ and low GCS (9-10/15). Nasal continuous positive airway pressure (CPAP) and intravenous fluid treatment were initiated. Blood gas analysis showed high anion-gap metabolic acidosis and high lactate level (Table 1). $\mathrm{CBC}$, biochemical values and coagulation profile were within normal limits. In the $12 \mathrm{~h}$ after exposure, a cyanide kit was provided, and hydroxocobalamin $(70 \mathrm{mg} / \mathrm{kg}$ ) infusion was administered. Nasal CPAP and intravenous fluid treatment were stopped $18 \mathrm{~h}$ after hospitalisation. He was discharged from the PICU after 2 days.

\begin{tabular}{|llllll|}
$\begin{array}{l}\text { Table } \\
\text { department }\end{array}$ & \multicolumn{3}{l}{ Blood gas parameters of patients at the emergency } \\
\hline Case & $\mathbf{p H}$ & $\mathbf{p C O}_{2}$ & $\mathbf{H C O}_{3}(\mathbf{m m o l} / \mathbf{L})$ & $\mathbf{B E}(\mathbf{m m o l} / \mathrm{L})$ & $\begin{array}{l}\text { Laktat } \\
\text { (mmol/L) }\end{array}$ \\
\hline 1 & 6.96 & 38 & 8.5 & 22 & 12 \\
\hline 2 & 7.11 & 29 & 9.1 & 20 & 13.5 \\
\hline 3 & 7.1 & 35 & 9.70 & 20 & 13.1 \\
\hline 4 & 7.25 & 36 & 15 & 20 & 9.58 \\
\hline
\end{tabular}

\section{Case 3}

A 2.5-year-old girl was admitted to the PED for vomiting and LOC after $2 \mathrm{~h}$ of eating four to five apricot seeds with her sibling. The initial evaluation of the patient revealed tachycardia (160 beats/min), prolonged capillary refill time (4 s), normotension $(100 / 50 \mathrm{mmHg})$ and low GCS (9/15). Nasal CPAP and intravenous fluid treatment were initiated. Blood gas analysis showed high anion-gap metabolic acidosis and high lactate level (Table 1). CBC, biochemical values and coagulation profile were within normal limits. The patient was transferred to PICU with a diagnosis of cyanide poisoning. Within $6 \mathrm{~h}$ of hospitalisation, hydroxocobalamin $(70 \mathrm{mg} / \mathrm{kg}$ ) was initiated. After $24 \mathrm{~h}$, all vital signs and laboratory findings returned to normal, and he was discharged from the PICU.

\section{Case 4}

A 3.5-year-old girl was admitted to the PED with complaints of abdominal pain, vomiting and weakness $2 \mathrm{~h}$ of eating four to five apricot seeds with her sibling (Case 3). The initial physical vital signs were as follows: a regular heartbeat of 130 beats/min, respiration rate of 25 breaths/min, blood pressure of $100 / 60 \mathrm{mmHg}$ with a capillary refill of $2 \mathrm{~s}$ and oxygen saturation of $98 \%$ via oxygen mask. Her GCS was 13 . High anion-gap metabolic acidosis and high lactate level were detected in blood gas analysis (Table 1). CBC, biochemical values and coagulation profile were within normal limits. The patient was hospitalised at the paediatry service with the diagnosis of cyanide poisoning. Antidote treatment was not required. After $24 \mathrm{~h}$, all vital signs and laboratory findings returned to normal, and she was discharged.

\section{Discussion}

In various regions of the world, foods containing cyanide are consumed. The seeds of fruits such as cherry, almond, apricot, peach, plum, lima bean, potato, radish, turnip, corn and cassava plant can be ranked among their nutrients. Apricot seeds involve natural amygdalin, and after ingestion, they produce cyanide by hydroxylation of glucosidase and emulsion enzymes. ${ }^{5,15}$ It is known that the cyanide content of apricot ranges between 0.089 and $2.17 \mathrm{mg} / \mathrm{g} .{ }^{4}$ The toxic level is $1 \mathrm{mg} / \mathrm{L}$, and consuming more than $3 \mathrm{mg} / \mathrm{L}$ is fatal. ${ }^{16}$ Children are more susceptible to cyanide poisoning than adults because of their low body mass and high basal metabolic rate. In literature, patients show symptoms of poisoning after eating 5-25 apricot seeds according to their age and weight. Based on the information obtained from the families of our patients, they ate 4-10 apricot seeds. There was no correlation between the number of apricot seeds ingested and clinical symptoms. ${ }^{6}$ 
Cyanide leads to anoxia by inhibiting cytochrome oxidase at the cellular level. Lactic acid production increases as a result of anaerobic metabolism, and metabolic acidosis with high anion-gap forms. The most affected organs are the heart, kidneys and lungs. In mild cases, vomiting, dizziness, metallic mouth taste, apathy, anxiety and hyperpnea have been observed. Following that, dyspnoea, bradycardia, arrhythmia, cyanosis and changes in consciousness can occur. In severe cases, progressive coma, convulsions, shock, pulmonary oedema and cardiovascular collapse can occur and result in death. ${ }^{17}$ The symptoms of our patients appeared 0.5-2 $\mathrm{h}$ after they had eaten the seeds, and their first complaint was vomiting. The three patients admitted in the PICU manifested unconsciousness, respiratory distress and apparent circulatory impairment findings. The laboratory tests showed metabolic acidosis with high anion-gap. Differential diagnoses included ketoacidosis, renal failure and drug and chemical substance intake (salicylate, phenformin/metformin, methanol, formaldehyde, ethylene glycol, paraldehyde, etc.) as they could also cause metabolic acidosis with high anion-gap. It is difficult to establish the diagnosis of cyanide poisoning. Food intake involving cyanide, abrupt impairment in a clinical situation, rapidly emerging metabolic acidosis and bitter almond smell in the breath are important clues for the diagnosis. ${ }^{4}$ In suspicious cases, a blood cyanide level can be measured; however, blood level and clinical findings are not always correlated. Blood level results are not necessary before treatment. ${ }^{18}$ We did not check the blood levels of our patients because their clinical and laboratory findings were very typical of cyanide poisoning, and also, the blood level could not be checked in any of the close centres. In these patients, the basic treatment approach is supportive treatment such as adequate airway management, oxygen and intravenous fluid. Gastric lavage and activated charcoal can be used in the early stages of poisoning. Sodium bicarbonate therapy has been recommended for patients with lactic acidosis.

For mild cases, supportive treatment is sufficient; on the other hand, antidote treatment must be given absolutely for cases with mental mood changes, severe metabolic acidosis, resistant convulsion and hypotension. Cyanide antidote kit (amyl nitrite, sodium nitrite and sodium thiosulfate), Dicobalt EDTA (Kelocyanor), Hydroxocobalamin (Cyanokit) and 4-dimethylaminophenol can be used as antidotes. In recent years increasing use of hydroxocobalamin; It forms nontoxic cyanocobalamin by binding to the cyanide molecule and provides its excretion with urine. ${ }^{11}$ Since it shows a rapid effect and does not have any serious adverse effects, it is an appropriate antidote, particularly in children. ${ }^{11}$ We applied $70 \mathrm{mg} / \mathrm{kg}$ hydroxocobalamin infusion for three patients with severe intoxication findings and ensured rapid clinical recovery in them. Supportive treatment was applied to the fourth patient displaying mild poisoning findings, and he was discharged from the hospital with healing.

There are a few studies in the literature evaluating cyanide poisoning cases due to apricot seed ingestion, particularly in children. The first case was published in Turkey in 1964. ${ }^{19}$ In the literature, three paediatric patients, including two based on apricot seed intake and one bitter almond intake, were reported between 2010 and 2017.17,20,21 A total of seven paediatricc patients received hydroxocobalamin as an antidote in the literature. 6,21

In conclusion, cyanide poisoning should be considered in cases with sudden onset of vomiting, change of consciousness, circulatory disorder and high anion-gap metabolic acidosis, particularly in patients with a history of apricot seed consumption. It should be kept in mind that antidote treatment is life saving in patients with severe symptoms.

\section{Ethics}

Informed Consent: A consent form was completed by all participants.

Peer-review: Internally and externally peer reviewed.

\section{Authorship Contributions}

Surgical and Medical Practices: Y.B., I.Y., P.Y.Ö., A.B., Concept: Y.B., I.Y., P.Y.Ö., A.B., Design: Y.B., I.Y., P.Y.Ö., A.B., Data Collection or Processing: Y.B., I.Y., P.Y.Ö., A.B., Analysis or Interpretation: Y.B., I.Y., P.Y.Ö., A.B., Literature Search: Y.B., I.Y., P.Y.Ö., A.B., Writing: Y.B., I.Y., P.Y.Ö., A.B.

Conflict of Interest: No conflict of interest was declared by the authors.

Financial Disclosure: The authors declared that this study received no financial support.

\section{References}

1. Uysal C, Karapirli M, Uzun I. Cyanide poisining: anunusual case. Journal of Harran University Medical Faculty. 2011;8:119-22.

2. Lasch EE, Raghda ES. Multiple cases of cyanide poisoning by apricot kernels in children from Gaza. Pediatrics. 1981;68:5-7.

3. Özkan G, Karcı I, Ateş AG, Anıl M, Özkan I, et al. Acute Cyanide Poisoning That Occurs With Apricot Kernel Eating In Two Sisters. Smyrna medical journal. 2013;10:47-9.

4. Taylor J, Roney N, Harper C, Fransen ME, Swarts S. Toxicological profile for cyanide (update). US Department of Health and Human Services, Public Health Service, Agency for toxic substances and disease registry. Atlanta. 2006:42-184.

5. Suchard JR, Wallace KL, Gerkin RD. Acute cyanide toxicity caused by apricot kernel ingestion. Ann Emerg Med. 1998;32:742-4.

6. Akyildiz BN, Kurtoğlu S, Kondolot M, Tunç A. Cyanide poisoning caused by ingestion of apricot seeds. Annals of Tropical Paediatrics. 2010:30:39-43 
7. Rosenow F, Herholz K, Lanfermann H, Weuthen G, Ebner R, et al. Neurological sequelae of cyanide intoxication-the patterns of clinical, magnetic resonance imaging, and positron emission tomography findings. Ann Neurol. 1995;38:825-8.

8. Chen F, Jiang L, Yang B. Visual loss caused by acute cyanide poisoning: a case report. Clin Toxicol. 2011;49:121-3.

9. Kupper J, Schuman M, Wenning R, Gorber U, Mittelholzer A, et al. Cyanide poisoning associated with the feeding of apricot kernels to dairy cattle. Vet Rec 2008;162:488-9.

10. Gonzalez ER. Cyanide evades some noses, overpowers others. JAMA. 1982;2:19-22.

11. Geller RJ, Barthold C, Saiers JA, Hall AH. Pediatric cyanide poisoning: causes, manifestations, management, and unmet needs. Pediatrics. 2006;118:2146-58.

12. Cescon DW, Juurlink DN. Discoloration of skin and urine after treatment with hydroxocobalamin for cyanide poisoning. CMAJ. 2009;180:251.

13. Forsyth JC, Mueller PD, Becker CE, Osterloh J, Benowitz NL, et al. Hydroxocobalamin as a cyanide antidote: safety, efficacy and pharmacokinetics in heavily smoking normal volunteers. J Toxicol Clin Toxicol 1993;31:277-94.

14. Hall AH, Dart R, Bogdan G. Sodium thiosulfate or hydroxocobalamin for the empiric treatment of cyanide poisoning? Ann Emerg Med 2007:49:806-13.
15. Cigolini D, Ricci G, Zannoni M, Codogni R, De Luca $M$, et al. Hydroxocobalamin treatment of acute cyanide poisoning from apricot kernels. Emerg Med J. 2011;28:804-5.

16. Fortin JL, Waroux S, Giocanti JP, Capellier G, Ruttimann M, et al. Hydroxocobalamin for poisoning caused by ingestion of potassium cyanide: a case study. J Emerg Med 2010;39:320-4.

17. Sauer H, Wollny C, Oster I, Tutdibi E, Gortner L, et al. Severe cyanide poisoning from an alternative medicine treatment with amygdalin and apricot kernels in a 4-year-old child. Wien Med Wochenschr. 2015;165:185-8

18. Barceloux DG. Cyanogenic foods (cassava, fruit kernels, and cycad seeds). Dis Mon. 2009;55:336-52.

19. Sayre JW, Kaymakcalan S. Cyanide poisoning from apricot seeds among children in Central Turkey. N Engl J Med 1964;270:1113-8.

20. Nader R, Mathieu-Daudé JC, Deveaux M, Faure K, Hayek-Lanthois $M$. et al. Child cyanide poisoning after ingestion of bitter almonds. Clin Toxicol (Phila). 2010;48:574-5.

21. Akıl M, Kaya A, Ustyol L, Aktar F, Akbayram S. Acute cyanide intoxication due to apricot seed ingestion. J Emerg Med. 2013;44:285-6. 